\title{
Interesting Observations of a Deer
}

\section{by A. J. Hruska, Gerald, Sask}

Have you ever seen a deer rubbing its knees (hocks) together? Perhaps very few of you have, as deer are very shy creatures. It is only after they have become used to your being near them that they will perform some of their antics in your sight.

Two winters ago I observed these actions of a White-tailed Deer almost daily. That winter the deer were starving but this one made himself quite at home at my straw stack and oat granary. After hauling the manure out in the morning I would proceed to the oat straw stack for straw. Almost every day I would find the big deer bedded down in the dry straw. Sometimes the deer would leap five or six feet to get to the top of the straw cut I was using. At first, when I approached the stack the deer would leave. As I came to the stack daily, he became tamer. Finally, I could drive right up to the stack and stop before he got off the straw. After coming off the stack he would walk over to the granary for his oats. If there wasn't enough on the ground he would lick at the crack and make the oats run out.

After breakfast, the deer would climb up on the big snowbank and watch me pitching straw. Then, having satisfied his curiosity, he would saunter off about 150-200 feet. There he would perform his antics. At this point he would buckle up slightly, put his hind feet together and start to tramp, rubbing his hocks together. This lasted about two or three minutes. His actions reminded me of a turkey tom during breeding season, but they did not seem to be of the same order. After tramping in this fashion for a time he woul lift his right hind leg and lick th inside of his left hock. This action reminded me of cattle licking thei lousy spots. Sometimes this antic wa repeated a few steps further o Then the animal would saunter of to the valley and join the othe starving deer.

Now what conclusions can w reach? The deer wasn't voiding a this was performed at the granary It's not likely to be sexual behaviou An examination of the hock of deer will reveal that on the insid is a large triangular patch of stif bristly hair. If you work your finge in this area and smell the exudatio you will find that it has an agreeabl odor of pine. So, the only conclu sion we can arrive at is that the dee was cleaning out his "ears". Anybod agree?

NOTE: Olfactory signals probably play : important role in the lives of wild animals bi their function is little understood. Scent glan are well known in mammals and are located dozens of different places in different specie The metatarsal gland described by Hruska present in both sexes in both species of deer. the White-tailed Deer (Odocoileus virginianus the actual gland is about one inch in length; the Mule Deer (Odocoileus hemionus) gland is about five inches long. One wou hesitate to say without further knowledge the normal behaviour whether the action scribed above was an instinctive behaviour help distribute the scent material or wheth it was simply a response to an irritation $\mathrm{pr}$ duced by excessive secretion of the gland suggested by Hruska. It may well be both.

Mr. Hruska's report is a good example careful cbservation and recording. Even, if do not know the exact nature of the phen menon the published observation remains a permanent record which can be studied as which contributes to our further knowledge a wild animal. The material published in $t$. Blue Jay is not only of interest to us no but will continue to be of interest as long people are interested in natural history. T day's information is tomorrow's knowledge. R.W.N.

\section{Further Record of Raccoon in Saskatchewan}

by Stanley M. Durr, Bromhead, Sask.

This winter I trapped a raccoon on the creek here (Long Creek). My father homesteaded here in 1903 and says it is the first he had ever seen in these parts.

\section{Additional Gray Squirrel Information}

by Robert W. Nero,

Sask Museum of Nat. Hist.

The Museum has received a Gr: Squirrel (Sciurus carolinensis) fro: W. Brownlee, Rose Valley (about : miles south of Tisdale). This squirr was reportedly killed in March, 195 